\title{
Influence of Work-Family-Conflict and Gender on Parenting Styles among Working Parents in Makurdi Metropolis
}

\author{
Judith Ayangeawam Mase, PhD \\ Tertindi Lordsent Tyokyaa, MSc \\ Benue State University, Makurdi - Nigeria
}

doi: 10.19044/esj.2016.v12n20p299 URL:http://dx.doi.org/10.19044/esj.2016.v12n20p299

\begin{abstract}
Parenting styles provide the basis for many developmental outcomes during childhood and beyond. Proper parenting is required for the children to properly adjust in their adult life, as poor parenting has been considered a risk factor for problem behaviour in childhood and later adulthood. This study therefore, examines the influence of work-family conflict on parenting styles among working parents in Makurdi metropolis. A cross-sectional survey was adopted in carrying out the study. A total of 236 working parents involving 108(45.8\%) male and 128(54.2\%) female parents within the age range of 23-54 years, mean age of $31.84,(S D=8.96)$ were sampled from a population of working parents in Makurdi metropolis. The Parental Care Scale (Baunmnd, 1991) and Work-Family Conflict Scale (Netemeyer, et al., 1996) were used for the purpose of data collection. Simple linear regression analysis and MANOVA were used in testing the hypotheses. Results revealed a significant influence of work-family conflict on parenting styles among the working parents. A significant difference was also found between male and female working parents on parenting styles. It was concluded that work-family conflict is a significant determinant of parenting styles and that differences in parenting styles also exist between male and female parents. Implications for working parents were discussed and recommendations were also made.
\end{abstract}

Keywords: Work, work-family conflict, working parents, parenting styles

\section{Introduction}

The period of childhood is often portrayed as stressful for both parents and the children. Children undergo a number of developmental adjustments including biological, cognitive, emotional and social changes on their way to becoming adults. Parenting styles provide the basis for many 
developmental outcomes during childhood and beyond (Gadeyne, Ghesquiere, \& Onghena, 2004). Proper parenting is required for the children to properly adjust in their adult life, as poor parenting has been considered a risk factor for problem behaviour in childhood and later adulthood. For instance, Kordi and Baharudin (2010) reported a strong relationship between children's school achievement and parenting attitude and style. Also, Milevsky, Schlechter, Netter, and Keehn (2007) noted that children of authoritative parents had increased self-esteem, healthy life-satisfaction and lower instances of depression when compared to children of parents with other parenting styles such as authoritarian and permissive. On the other hand, Reid, Webster-Stratton and Baydar (2004) observed that parents of children with antisocial behaviour are likely to be less positive, more permissive and inconsistent, and use more violent and critical discipline. These are indications that parenting styles are related to different behavioural outcomes in children both desirable and undesirable. The strong association between parenting styles and children's behavioural outcomes informs the need to understand some of the factors influencing parenting styles.

Parenting is a family task that requires care and attention. However, this task seems to be distorted by the disagreement between the forces of work and family, best known in organisational literature as 'Work-Family Conflict' (WFC) which serves as an important source of stress for parents and may interfere with their parental life. The continually increasing amount of dual-parent and single-parent families participating in the workforce has caused competing responsibilities as parents and employees, leading to high levels of stress as well as problems at home and in the workplace. This is even made worst as only about $2 \%$ of working parents are likely to seek parenting assistance from professional avenues (Sanders, Haslam, Stallman, Calam \& Southwell, 2011). This has become an issue of concern considering the fact that time which should have been given to the children at home is shared with work responsibility. As a result, working parents may have different parenting experiences and consequently adopt different styles of raising their children. For instance, Erdwins, Buffardi, Casper and O’Brien (2001) reported that mothers with high work- family conflict felt less competent as parents. These mothers may suffer from a reduction in parental, marital, and life satisfaction related to their inability to carry out their nurturing role as associated with being "good” mothers (Hays, 1996), and may influence the way such mothers raise their children. These working parents may have difficulty maintaining the home, nurturing relationships within the family, and caring for the children.

Although there is a volume of research indicating that there is a negative influence of WFC on parenting, some other researchers have argued that it could rather stimulate positive parenting attitude and practices. 
Guendouzi (2006) noted that working mothers often express guilt over being away from their children and this guilt may motivate employed mothers with high work-family conflict to invest more effort into positive parenting. These women may hope that by devoting additional attention to family, it will help them feel like "good" women and mothers. It has been found that employed mothers, more so than non-employed mothers, structure their weekend hours so they are actively engaged with their children in either play, reading a book, or helping with homework (Zick, Bryant \& Osterbacka, 2001; Bianchi, Milkie, Sayer \& Robinson, 2006). Given the conflicting position of researchers on the role of WFC on parenting styles, this study further investigates the influence of work-family conflict on parenting styles among working parents in Makurdi metropolis.

\section{Literature review \\ Parenting Styles}

Parenting style is one of the concepts that have been studied extensively in human development (Baldwin, Mcintyre, \& Hardaway, 2007). It is considered an important determinant of several aspects of children's outcome (Gadeyne, Ghesquiere, \& Onghena, 2004). The notion have been related to children and adolescents' academic achievement (Lamborn, Mounts, Steinberg, \& Dornbusch, 1991), optimism (Baldwin, Mclntyre, \& Hardaway, 2007), confidence (Strage \& Brandt, 1999), motivation (Gonzalez \& Wolters, 2006), externalizing problem behaviour and attention problems (Gadeyne, et al., 2004).

Researchers have used different ways to conceptualize parenting. Baumrind (1996) views parenting as a combination of parental "demandingness" and "responsiveness" with respect to parent-child interactions. Demandingness is defined as high parental expectations for a child's behaviours. Responsiveness on the other hand is defined as the parent's prompt response to a child's needs as well as acceptance and encouragement of the child's point of view. When parents are high or low on these parental characteristics, it results in three parenting styles which include permissive parenting, authoritarian parenting and authoritative parenting. Permissive parents are low on demandingness which means they are less concerned with whether the child follow norms for appropriate behaviour expectations but are highly responsive to the child's needs. In contrast, an authoritarian parent is highly demanding and expects the child to follow strict behaviour rules without question but is less responsive to a child's point of view. Lastly, an authoritative parent is highly demanding and expects appropriate child behaviour but is also highly responsive to the child's needs and encourages the children to discuss their feelings (Baumrind, 1996). Baumrind's (1978) three parenting styles of authoritarian, 
permissive, and authoritative are often used in studies investigating parenting styles in relation to diverse child outcome variables, such as academic achievement, self-confidence, aggression, delinquent behaviour, and substance abuse (Dornbusch et al., 1987; Hart, Nelson, Robinson, Olsen, \& McNeilly-Choque, 1998; Hill, 1995; Lamborn, Mounts, Steinberg, \& Dornbusch, 1991). Past research has also included a fourth parenting style called neglectful, which is characterized by low warmth and low control (Dekovic \& Gerris, 1992; Glasgow, Dornbusch, Troyer, Steinberg, \& Ritter, 1997; Lamborn et al., 1991; Leung \& Kwan, 1998). Maccoby and Martin (1983) call this parenting style Indifferent or Uninvolved. They describe these parents as emotionally detached. Indifferent, uninvolved or neglectful parents tend to keep their children at a distance, responding to child demands only to make them cease.

Of all the parenting styles, authoritative parenting is considered the best approach because it encourages children to develop more reasoning and personal responsibility which are positive for themselves and society. Baumrind (1966) described authoritative parents as parents who promote "verbal give and take," whereas authoritarian parents were described as wanting to shape, control, and evaluate the behaviour and attitudes of the child. Baumrind (1971) stated that children raised within authoritative homes engage in more "independent, and purposive behaviour," when compared with children from authoritarian and permissive households. The literature suggests that many children benefit from a democratically run household (Milevsky et al., 2007), however, other children may need more structure in order to adhere to behavioural guidelines (Greening, Stoppelbein, \& Luebbe, 2010). Children have fewer behaviour problems and better grades when parents had both high expectation and high involvement in their child's life (Amato \& Fowler, 2002). Other researchers have documented similar advantages for children with authoritative parents such as they demonstrate competent social interaction skills, self-reliant and independent problem solving, emotional well-being and overall psychological adjustment, and few maladaptive internalizing and externalizing behaviours (Grusec \& Goodnow, 1994; Pomerantz, Grolnick, \& Price, 2005). These children enjoy academic success, demonstrate socially responsible and prosocial forms of classroom behaviour, and competent relationships with their peers. They also report strong intrinsic interest in learning, positive beliefs about ability and control, and mastery goal orientations toward learning (Wigfield, Eccles, Schiefele, Roeser, \& Davis-Kean, 2006). On the other hand, authoritarian and permissive parenting styles were found to be negatively associated with higher grades (Dornbusch et al., 1987; Radziszewska, Richardson, Dent \& Flay, 1996). In another study of adolescents, Leung, Lau, and Lam (1998) found that academic achievement was negatively related to authoritarianism. 


\section{Work-Family-Conflict}

Greenhaus, Callanan and Godshalk (2000) defined work-family conflict (WFC) as conflict that exists when pressures from work and family roles are mutually incompatible, such as when participation in one role is made more difficult by virtue of participation in another role. Foley and Powell (1997) viewed work-family-conflict as a type of inter-role-conflict in which the work life requires more attention of an individual than his family life or vice versa, meaning that both are not accorded the demanded attention. Therefore, the role pressures from the work and family domains are mutually incompatible in some instances. This suggests that conflict between work and family is bidirectional which means work interferes with family (WIF) and family interferes with work (FIW) and that both are strongly correlated. The present study considers the two directions as separate domains and focuses only on work-to family conflict. It is therefore important to note that throughout the current study, the term work-family conflict is used to reflect conflict between work and family and not the other way round.

Work and family are two of the most important realms of adult life. These were traditionally studied as two separate, independent domains. This formed the breadwinner/homemaker template which was the norm in the 1950s when work and family were considered separate and primarily genderspecific domains (Kanter, 1977). While men were regarded as breadwinners, women were seen as homemakers. Following this notion, separate bodies of literature existed on the workplace and on the family, but the connection between the two was rarely studied. Workplace and government policies in the mid-1900s were then based on the assumption that someone was at home full-time to care for the needs of the family leaving the worker unbothered by outside demands (Kanter, 1977; Appelbaum, Bailey, Berg, \& Kalleberg, 2002; Moen, 2003). However, since the 1960's, there have been dramatic changes in the family and the workforce, including an increase in the number of women working in the paid labor force and more dual-career couples. In other words, work and family have become inseparable as the organisation determines the social status and financial position of the family members.

According to Greenhaus, et al. (2000), the traditional household where a husband works and a wife stays at home represents less than ten percent of all families in America. This reflects the increasing educational and career aspirations of women in today's society. Today, dual-earner couples or working parents are the norm, representing 54\% of married couples in the U.S. in 2001. This dyad is even more common among couples with children in the home, representing $64 \%$ of parental dyads and $57 \%$ of couples with children under the age of 6 in 2001 (U.S Bureau of Labor 
Statistics, 2002). This shows the high rate at which both parents (mother and father) engage in employment outside the home. DeSimone (2009) explains this dramatic increase in the numbers of dual career parents with increasing role and rights of woman in society and changing family values. Researchers have also noticed that the two-career lifestyle has increased in recent years due in one hand to the advancement in knowledge and on the other hand to the need for two incomes to maintain a certain status in living (Cherniss, 2000; Cherniss \& Mitilel, 2000).

Work-family conflict is particularly a problem for working parents. Working parents might be subjected to pressure in their attempts to balance their work and family responsibilities. Ugoani (2013) noted that work-family conflict is very common among working parents because they play several different roles in their lives and must deal with groups of other persons holding contrary expectations about their behaviours both at work and at home. At work, the mother whose husband or partner is equally at work is concerned about what is happening at home, and the father whose wife is at work will be concerned about how to pick the children from school back home and return to work. These role pressures present a serious source of conflict between work and family for dual- career parents and unfortunately, there is no best way of reconciling the conflict in favour of any one direction (Agulanna \&Agulanna, 2008).

The types of conflict that working parents can experience are timebased conflict, strain-based conflict and behaviour based conflict. This can be linked with inter-role conflict where one role is incompatible with another. Time-based conflict is experienced when roles compete for time. Time spent in one role cannot be spent in the other role, for example out-oftown business meetings can conflict with family dinners (Greenhaus, Collins \& Shaw, 2003). Bacharach, Bamberger and Conley (1991) agreed that time devoted in one role makes it difficult to fulfill requirements in another role. Strain-based conflict exists when the strain produced by one role affects performance in another role. Greenhaus, et a,l. (2000) indicated that work stressors can produce strain symptoms like tension, irritability, fatigue and depression. Finally, behaviour-based conflict occurs when the behaviour in one role is not necessarily appropriate for the other role (Netemeyer et al., 1996). For example, a person needs to be sensitive and caring at home, but at work an assertive, logical and impersonal approach may be required. The type of behaviour reflected at work might obviously be inappropriate at home.

\section{Work-family Conflict and Parenting Styles}

Work-family-conflict is often treated in the literature as an outcome variable instead of a predictor. Previous studies have focused on its 
antecedents such as level of employment, marital status, health, age, education, income, and timing of children (Becker \& Moen, 1999; Marks at el., 2001; Zick et al., 2001; Blair-Loy \& Dehart, 2003). Few studies however, have examined how work-family conflict affects the family generally and the children in particular. Mothers with high work-family conflict are found be more irritable, impatient or withdraw from children (Perry-Jenkins et al., 2000). In some cases, mothers with high work-family conflict can become depressed making it difficult for them to carry out daily tasks such as personal care, child care, cooking, cleaning, organizing, maintaining relationships, and working (Perry-Jenkins, Repetti \& Crouter, 2000). Maternal depression leaves children, and a spouse/partner with less social and emotional support.

Whereas the relationship between mother's employment and family outcomes is generally positive, work-family conflict has been shown to have negative effects. Investigators found that workers with high work-family conflict report more depression, physical ailments, fatigue, stress, and lower family life satisfaction (Frone, Russell, \& Cooper, 1997; Googins, 1991; Van Hooff, Geurts, Kompier \& Tans, 2006). Mother's compromised health can affect their parenting quality and parental satisfaction. For example, researchers found that depressed mothers have less clear home rules and are less likely to be viewed as an authority by their children than mothers without depression (Foster, et al., 2009). A child lacking parental guidance may be unsure how to interact in the world. In fact, delinquent youth often report having uninvolved or unsupportive parents (Simons, Johnson \& Conger, 1994).

Researchers have also claimed that work-family-conflict could stimulate more parental care and attension. Employed mothers may work harder to uphold the intensive mothering expectations by becoming a "supermom" (DeMeis \& Perkins, 1996). Some employed mothers believe it is the amount of maternal time spent interacting with children that is important to their development (Snyder, 2007). These mothers will take steps to "protect their investment in their children" by giving up their sleep, personal time, and own interest in order to have more time to invest in parenting (Becker \& Moen, 1999; Bianchi et al.,., 2000; Bianchi et al., 2006). It has been reported that when some employed mothers put more time into their parenting, they felt more competent as mothers (Milkie \& Peltola, 1999; Guendouzi, 2006). The combination of guilt and having internalized the intensive mothering ideology may encourage mothers to compensate by increasing their parenting as a response to high work-family conflict. This could thus, lead to positive parenting outcome.

Other empirical findings have also demonstrated the association between work-family-conflict and parenting styles either directly or 
indirectly. Gürsoy and Yildiz (2007) made a comparison of parental attitude perceptions in children of working and nonworking mothers and reported from the study that the work status of mothers has a significant impact on the parental perception of their children, in particular how loving or punishing children perceive their parents to be. Children of working mothers view their parents as more loving and less punishing compared to children of nonworking mothers. In another study, the link between work role stressors and fatherhood role salience and how each of those was associated with parenting stress and satisfaction with parenting and children's behaviour was examined using a sample of 473 fathers who were firefighters in the southcentral region of the U.S. The study revealed that work-family-conflict was associated with higher parenting stress and lower parenting satisfaction (Shrefflera, Meadowsa \& Davis, 2011). Also, working more than 60 hours per week significantly predicted lower satisfaction with children's behaviour. Fatherhood role salience factors were also associated with parenting stress and parenting satisfaction. These results highlight the importance of work-tofamily conflict in fathering research and suggest that the salience of the fatherhood role provides a contextual understanding for the relationship between work and parenting in fathers' lives.

Cho (2010) investigated the relationship between work-familyconflict (WFC) and three forms of parent-child interaction behaviour (PB): physical and recreational PB (PRPB), cognitive and academic-oriented PB (CAPB), and passive and maintenance-oriented PB (PMPB). Employed parents of early school-aged children $(n=201)$ participated in the survey. Results indicated that both time- and strain-based WFC were negatively related to two types of active PB, PRPB and CAPB. This indicates that parents with high WFC show less physical and recreational parent-child interaction behaviour (PRPB) as well as cognitive and academic parent-child interaction behaviour (CAPB). In another study, Nomaguchi and Johnson (2013) investigated employment, work-family conflict, and parenting stress among economically disadvantaged fathers, making use of data from the Fragile Families and Child Wellbeing Study. Results of the study show that current unemployment and greater work- family conflict, but not overwork, odd-jobs, and nonstandard hours, are related to more parenting stress for fathers. Similar patterns were found for mothers, except that work-family conflict is related to fathers' more than mothers' stress; and nonstandard schedule is related to less stress for mothers only. Current employment status and work-family conflict were the strongest predictors of fathers' but not mothers' stress. Results of this study suggest that pressures from work could make parenting very stressful for both mother and father and has the tendency to influence their parenting style. 


\section{Gender differences in Parenting Styles}

Although the relationship between parenting and outcomes for children and adolescents has been examined, differences between maternal and paternal parenting styles have received less attention in the research literature. There are however, some evidences in the literature on parenting which suggest possible differences between fathers and mothers' style of parenting. Conrade and Ho (2007) examined differential parenting styles for fathers and mothers using a sample of 617 university students. Their findings revealed a significant gender-based difference for authoritative and permissive styles of parenting. Mothers, rather than fathers, were perceived to be more likely to use these styles. Fathers were perceived by male respondents to be more likely to use an authoritarian style. Mothers were perceived to be more likely to use an authoritative style by female respondents and a permissive style by male respondents. In another study, Winsler, Madigan and Aquilino (2005) investigated perceived similarities and differences in parenting styles between mothers and fathers in the same family. In the study, fathers perceived their spouses to be more authoritative, more permissive, and less authoritarian than themselves, whereas mothers only perceive themselves to be more authoritative than fathers. It has also been found that permissive parenting is more likely among mothers from egalitarian households whereas authoritarian parenting was more likely among those from traditional households. On the other hand, authoritative parenting is more likely among fathers from egalitarian households and disengaged parenting was more likely among those from traditional households (Sabattini \& Campbell, 2004). A study by Bentley and Fox (1991) revealed that that mothers are more nurturing compared to fathers which suggest that the mothers can be less authoritarian and more authoritative and permissive. Similarly, McKinney and Renk (2008) found that mothers and fathers use different parenting styles for their sons and daughters.

On the whole, literature on work-family conflict has suggested that the phenomenon is an issue for working parents and could affect their way of interacting with the children. There are also indications that differences exist between mothers' and fathers' style of parenting irrespective of their experience of work-family conflict. Based on this observation, the following hypotheses were tested in this study.

\section{Hypotheses}

i. There will be a significant influence of work-family conflict on parenting styles among working parents in Makurdi metropolis.

ii. There will be a significant difference between fathers' and mothers' style of parenting among working parents in Makurdi metropolis. 


\section{Method}

\section{Design}

This study employed cross-sectional survey design. This is the type of design in which data is collected from a sample of individuals to make inferences about a population of interest at a point in time. This design is suitable for this study in the sense that data collected from a cross-section of working parents was used to make inferences about their parenting styles.

\section{Participants}

The participants for this study were 236 working parents randomly sampled from the population of civil servants in Makurdi metropolis. Their ages ranged between 23-54 years with mean age of $31.84(\mathrm{SD}=8.96)$. They were 108(45.8\%) male and 128(54.2\%) female civil servants working within Makurdi metropolis of Benue State, Nigeria.

\section{Measurements}

\section{Parenting styles}

These were measured using the 20-item Parental Care Scale originally developed by Baumnd (1971) to measure what children perceive as the styles or approaches that their parents dominantly use in taking care of them. The instrument was adopted for use with parents in the present study. And for that reason, the items were modified to suit the population of parents. For instance, items such as "My parents try to direct my activities only when necessary" have been modified to become "I try to direct the activities of my children only when necessary". The scale measures three principal parenting styles: Authoritarian style, Permissive style and Authoritative. Baumnd (1991) provided the original psychometric properties for American samples. The author reported an internal consistency alpha coefficient of .86 for the scale. The instrument is scored 'Yes' or 'No' with 1 point given for each 'Yes'.

\section{Work Family Conflict}

This variable was measured using the Work-to-family conflict scale by Netemeyer, Boles and McMurrian (1996) which is a validated, existing instrument that includes time and strain based components of conflict. The 10-item scale contained five items measuring family-to-work conflict and five items measuring work-to-family conflict. Using a 5- point Likert scale, participants are asked to indicate the extent to which they agree with each item. Responses ranged from 1 (strongly disagree) to 5 (strongly agree). High scores on this scale represent high WFC while low scores represent low WFC respectively. According to Netemeyer et al., (1996), the internal consistencies of both scales are adequate, with alpha estimates ranging from 
.83 to .89 , and an average alpha of .88 for Work Family Conflict (WFC), and of .86 for Family Work Conflict (FWC) across three samples. Tsai (2008) also reported internal consistency of .92 and .90 for work family conflict and family work conflict subscales respectively.

\section{Data Analysis}

Preliminary analyses were conducted using descriptive statistics. These include the use of frequencies, simple percentages, mean and standard deviation for the analysis of demographic characteristics of the participants such as sex, age and level of education. Thereafter, simple linear regression, simple linear regression and multivariate analysis of variance (MANOVA) were used to test the hypotheses. While simple linear regression analysis was used to examine the influence of work-family-conflict on parenting styles, the multivariate analysis of variance (MANOVA) was used to test for differences between male and female parents on the different parenting styles.

\section{Results}

Two hypotheses were tested using regression as well as multivariate analysis. The results obtained are presented in Tables 1 \& 2 according to the hypotheses.

Table 1: Simple linear regression analysis showing influence of work-family conflict on parenting styles among working parents in Makurdi metropolis

\begin{tabular}{cccccccc}
\hline Variable & $\mathrm{R}$ & $\mathrm{R}^{2}$ & $\mathrm{df}$ & $\mathrm{F}$ & $\beta$ & $\mathrm{t}$ & $\mathrm{p}$ \\
\hline Constant & .374 & .140 & 1,234 & 37.942 & & 10.426 & .000 \\
WFC & & & & & .374 & 6.160 & .000 \\
\hline
\end{tabular}

\section{WFC=Work-Family-Conflict}

The result presented in Table 1 revealed that work-family conflict has a significant influence on parenting styles among working parents in Makurdi metropolis $\left[\mathrm{R}^{2}=.140, \mathrm{~F}(1,234)=37.942, \mathrm{p}<.001\right]$. The $\mathrm{R}^{2}$ value indicates that work-family conflict explained $14.0 \%$ of the total variance observed in parenting styles among the working parents. Hypothesis one was therefore confirmed.

Table 2: MANOVA showing sex differences on parenting styles among working parents

\begin{tabular}{|c|c|c|c|c|c|c|c|}
\hline Effect & & Value & $\mathbf{F}$ & $\begin{array}{l}\text { Hypothesis } \\
\text { df }\end{array}$ & $\begin{array}{l}\text { Error } \\
\text { df }\end{array}$ & Sig. & $\begin{array}{c}\text { Partial } \\
\text { Eta } \\
\text { Squared }\end{array}$ \\
\hline \multirow{5}{*}{ Intercept } & Pillai’s Trace & .97 & 2875.74 & 3.00 & 232.00 & .000 & .974 \\
\hline & Wilks’ Lambda & .026 & 2875.74 & 3.00 & 232.00 & .000 & .974 \\
\hline & Hotelling's Trace & 37.19 & 2875.74 & 3.00 & 232.00 & .000 & .974 \\
\hline & $\begin{array}{c}\text { Roy’s Largest } \\
\text { Root }\end{array}$ & 37.19 & 2875.74 & 3.00 & 232.00 & .000 & .974 \\
\hline & Pillai's Trace & .242 & 24.71 & 3.00 & 232.00 & .000 & .242 \\
\hline
\end{tabular}




\begin{tabular}{cccccccc}
\hline \multirow{3}{*}{ Sex } & Wilks' Lambda & .758 & .758 & 3.00 & 232.00 & .000 & .242 \\
& Hotelling’s Trace & .320 & 24.71 & 3.00 & 232.00 & .000 & .242 \\
& Roy's Largest & .320 & 24.71 & 3.00 & 232.00 & .000 & .242 \\
& Root & & & & & & \\
\hline
\end{tabular}

The result of MANOVA presented in table 2 showed that there is a statistically significant sex difference on parenting styles, [Wilks' Lambda=.758, $\mathrm{F}(3,232) 24.709, \mathrm{p}=.000$, Partial Eta Square $=.242]$. The Partial Eta Square value (.242) shows that sex accounted for $24.2 \%$ of the difference observed in parenting styles. Further observation of the univariate analysis showed that there is a statistically significant sex difference for permissive parenting, $[\mathrm{F}(1,234)=16.717, \mathrm{p}<.001$, Partial Eta square $=.883$ ], and authoritative parenting $[\mathrm{F}(1,234)=58.88, \quad \mathrm{p}<.001$, Partial Eta square $=.201$ ] respectively. A further comparison of the mean scores of males and females on the two parenting styles revealed that male working parents scored higher on permissive parenting (Mean=36.54, $\mathrm{SD}=12.02$ ) than female working parents (Mean=30.06, SD=.12.204); and, female working parents scored higher on authoritative parenting (Mean=49.65, $\mathrm{SD}=.6 .597$ ) when compared to their male counterpart (Mean=39.90, SD=.12.457) respectively. Hypothesis two was therefore confirmed.

\section{Discussion}

This study investigated the relationship between work- family conflict and parenting styles among working parents in Makurdi metropolis. Two hypotheses were postulated and tested using different statistical tools. The results obtained from the analysis of data are discussed below according to the hypotheses tested.

The first hypothesis stated there will be a significant influence of work-family conflict on parenting styles among working parents in Makurdi metropolis. This hypothesis was tested using simple linear regression and the result confirmed that work-family conflict explained $14.0 \%$ of the variance in parenting styles among working parents. This finding means that a reasonable proportion of the difference in parenting styles is determined by work-family conflict. This is to say that people with higher work-family conflict in most cases will differ from those with low work- family conflict on parenting styles. This is made possible because, parenting has a link with a parents' emotional state and therefore, when work-family conflict generates a state of psychological distress for the parents, they may be influenced by these emotions in their act of parenting. This finding is in line with Gursory and Yildiz (2007) who found that work status of mothers impacted on the perception of their parenting styles. They reported that working mothers were perceived by their children as more loving and less punishing compared to non-working mothers which implies an authoritative 
parenting style among working mothers. The finding also agrees with Shrefflera, Meadowsa and Davis (2014) who also found significant influence of work-family conflict on parenting styles. This finding has therefore, given credence to several other studies which have with similar finding.

The second hypothesis stated that there will be a significant difference between fathers' and mothers' style of parenting among working parents in Makurdi metropolis. This hypothesis was tested using One-Way multivariate analysis of variance (MANOVA) and it was found that there is a statistically significant sex difference on parenting styles. The results revealed a statistically significant sex difference for permissive parenting and authoritative parenting but not for authoritarian parenting style. It was observed that male working parents scored higher on permissive parenting compared to their female counterpart. On the other hand, female working parents scored higher on authoritative parenting compared to their male counterpart. This provides evidence to the speculation that mothers are better on childcare and parenting compared to fathers. Mothers spend more time with their children and therefore, have more opportunities to understand the needs of their children. Fathers in most cases are scarce at home and may not care much about the children making them (fathers) more permissive parents than mothers. This finding is congruent with several earlier findings such as that of Conrade and Ho (2007) who examined parenting styles for father and mothers and found that mothers were more permissive and authoritative in contrast to fathers who were more authoritarian. It also tallies with Winsler, Madigan and Aquilino (2005) who found that mothers were rated higher on permissive and authoritative parenting styles than the fathers.

\section{Conclusion/recommendations}

It is concluded from the findings of this study that work-family conflict is a significant determinant of parenting styles among working parents. Also, there are differences in style of parenting adopted by fathers and mothers in raising their children. It was therefore recommended that special training programmes should be organised for working parents to educate them on how to manage work-family conflict so that it will not affect their way of parenting. This could be organised either by the employers or volunteer organisations like non-governmental organizations (NGOs). Parents, especially fathers should learn to structure their work schedule so as to create and spend more time with their children in order to reduce the work-family gap.

\section{References:}

Agulanna, G. N. \& Agulanna, E. C. (2008). Stress and the Nigerian woman: A victim of multiple roles. $1^{\text {st }}$ Edition, Owerri, Chin and Chis Press. 
Amato, P. R., \& Fowler, F. (2002). Parenting Practices, Child Adjustment, and Family Diversity. Journal of Marriage and the Family, 63(3), 703-716. Appelbaum, E., Bailey, T., Berg, P., \& Kalleberg, A. L. (2002). Shared work valued care. Washington, D.C.: Economic Policy Institute.

Bacharach, S. B., Bamberger, P., \& Conley, S. (1991). Work- home conflict among nurses and engineers: Mediating the impact of role stress on burnout and satisfaction at work. Journal of Organisational Behaviour, 12, 39-53.

Baldwin, D., McIntyre, A., \& Hardaway, E. (2007). Perceived parenting styles on college students’ optimism. College Student Journal, 41(3), 550557.

Baumrind, D. (1978). Parental disciplinary patterns and social competence in children. Youth and Society, 9, 239-276.

Baumrind, D. (1996). The discipline controversy revisited. Family Relations, 45, 405- 414.

Baumrind, D., (1991). Parenting styles and adolescent development. In: Brooks-Gunn, J., Lerner, R., Peterson, A.C. (Eds.), The Encyclopedia of Adolescence. Garland, New York.

Becker, P. E. \& Moen, P. (1999). Scaling Back: Dual-Earner Couples' Work-Family Strategies. Journal of Marriage and the Family, 61(4), 9951007.

Bentley, K.S. \& Fox, R.A. (1991). Mothers and fathers of young children: comparison of parenting styles. Psychological Reports, 69(1), 320-322.

Bianchi, S. M. (2000). Maternal employment and time with children: Dramatic change or surprising continuity. Demography, 37(4), 401-414.

Bianchi, S. M., Milkie M. A., Sayer, L. C., \& Robinson, J. P. (2006). Changing Rhythms of American Family Life. New York: Russell Sage Foundation.

Blair-Loy, M. \& Dehart, G. (2003). Family and Career trajectories among African American Female Attorneys. Journal of Family Issues, 24, 908-933.

Cherniss, C, \& Mitchel, A. (2000). Promoting Emotional Intelligence in Organisations: Making Training in Emotional Intelligence Effective, August Issue: ASTD.

Cherniss, C. (2000). Emotional Intelligence: What it is and Why it Matters. Paper Presented at the Annual Meeting of the Society for Industrial and Organisational Psychology, New Orleans, L.A.

Cho, E. (2010). Examining the Relationship Between Work-toFamily Conflict and Parenting Behaviour. Graduate thesis, University of South Florida.

Conrade, G. \& Ho, R. (2001). Differential parenting styles for fathers and mothers. Australian Journal of Psychology, 53(1), 29-35. 
Dekovic, M., \& Gerris, J. R. M. (1992). Parental reasoning complexity, social class, and childrearing behaviours. Journal of Marriage and the Family, 54, 675-685.

DeMeis, D. K. \& Perkins, H. W. (1996). Supermoms” of the nineties: Homemaker and employed mothers' performance and perceptions of the motherhood role. Journal of Family Issues, 17, 777-792.

Desimone, L. M. (2009). Improving impact studies of teachers' professional development: Toward better conceptualizations and measures. Educational Researcher, 38, 181-200.

Dornbusch, S. M., Ritter, P. L., Leiderman, P. H., \& Roberts, D. F. (1987). The relation of parenting style to adolescent school performance. Child Development, 58, 1244-1257.

Erdwins, C. J., Buffardi, L. C., Casper, W. J., \& O’Brien, A. S. (2001). The Relationship of Women's Role Strain to Social Support, Role Satisfaction, and Self-Efficacy. Family Relations, 50(3), 230-238.

Foley, A. and Powel, G. N. (1997). Re-conceptualizing Work- family Conflict for Business/Management Partners: A Theoretical Model. Journal of Small Business Management, 35(4), 36 - 47.

Foster, C.W., Webster, M.C., Weissman, M.M., Pilowsky, D.J., Wickramaratne, P.J., Talati, A., et al. (2009). Remission of maternal depression: Relations to family functioning and youth internalizing and externalizing symptoms. Journal of Clinical Child \& Adolescent Psychology, 37(4), 714-724.

Frone, M. R., Russell, M., \& Cooper, M. L. (1997). Relation of work-family conflict to health outcomes: A four-year longitudinal study of employed parents. Journal of Occupational and Organisational Psychology, 70, 325335.

Gadeyne, E., Ghesquiere, P. \& Onghena, P. (2004). Longitudinal relations between parenting and child adjustment in young children. Journal of Clinical and Adolescents Psychology, 33, 347-358.

Glasgow, K. L., Dornbusch, S. M., Troyer, L., Steinberg, L., \& Ritter, P. L. (1997). Parenting styles, adolescents’ attributions, and educational outcomes in nine heterogeneous high schools. Child Development, 68, 507-529.

Gonzalez, A.L. \& Wolters, C.A. (2006). The relations between perceived parenting practices and achievement motivation in mathematics. Journal of Research in Childhood Education, 21, 203-218.

Googins, B. K. (1991). Work/Family Conflicts: Private Lives- Public Responses. New York: Auburn House.

Greenhaus, J. H., Callanan, G. A. \& Godshalk, V. M. (2000). Career management (3rd ed). Orlando: Dryden. 
Greenhaus, J. H., Collins, K. M. \& Shaw, J. D. (2003). The relation between work-family balance and Quality of Life. Journal of Vocational Behaviour, 63(2003), 510-531.

Greening, L., Stoppelbein, L., \& Luebbe, A. (2010). The moderating effects of parenting styles on African-American and Caucasian children's suicidal behaviours, 39, 357-369.

Grusec, J. E., \& Goodnow, J. J. (1994). Impact of parental discipline methods on the child's internalization of values: A reconceptualization of current points of view. Developmental Psychology, 30(1), 4-19.

Guendouzi, J. (2006). The Guilt Thing: Balancing Domestic and Professional Roles. Journal of Marriage and Family, 68, 90 1-909.

Gursoy, F. \& Yildiz, M. B. (2007). A Comparison of Parental Attitude Perceptions in Children of Working and Nonworking Mothers. Social Behaviour and Personality: An International Journal , 35(5),

Hart, C. H., Nelson, D. A., Robinson, C. D., Olsen, S. F., \& McNeillyChoque, M. K. (1998). Overt and relational aggression in Russian nurseryschool-age children: Parenting style and marital linkages. Developmental Psychology, 34, 687-697.

Hays, S. (1996). Cultural Contradictions of Motherhood. New Haven, CT: Yale University Press.

Hill, N. E. (1995). The relationship between family environment and parenting style: A preliminary study of African American families. Journal of Black Psychology, 21, 408-423.

Kanter, R.M. (1977). Work and family in the United States: A critical review and agenda for research and policy. New York, NY: Russell Sage Foundation.

Kordi, A. \& Baharudin, A. (2010). Parenting Attitude and Style and Its Effect on Children's School Achievements. International Journal of Psychological Studies, 2(2), 217 - 222.

Lamborn, S. D., Mounts, Steinber \& Bornbusch (1991). Patterns of competence and adjustment among adolescents from authoritative, authoritarian, indulgent, and neglectful families. Child Development, 62, $1049-1065$.

Leung, K., Lau, S., \& Lam, W. L. (1998). Parenting styles and academic achievement: A crosscultural study. Merrill- Palmer Quarterly, 44, 157-172.

Maccoby, E. E., \& Martin, J. A. (1983). Socialization in the context of the family: Parent-child interaction. In P. H. Mussen (Ed.), Handbook of child psychology. Vol. 4: Socialization, personality, and social development (pp. 1-10 1). New York: Wiley.

Marks, S. R., Huston, T. L., Johnson, E. M \& MacDermid, S. M. (2001). Role Balance among White Married Couples." Journal of Marriage and the Family, 63(4), 1083- 1098. 
McKinney, C. \& Renk, K. (2008). Differential Parenting Between Mothers and Fathers: Implications for Late Adolescents. Journal of Family Issues , 29(6), 806-827.

Milevsky, A., Schlechter, M., Netter, \& S., Keehn, D. (2007). Maternal and paternal parenting styles in adolescents: Associations with self-esteem, depression and life- satisfaction. Journal of Child and Family Studies, 16, 39 $-47$.

Milkie, M. A. \& Peltola, P. (1999). Playing All the Roles: Gender the WorkFamilyBalancing Act. Journal of Marriage and the Family, 6 1(2), 476-490.

Moen, P. (2003). It's about time: Couples and careers. Ithaca, NY: Cornell University Press.

Netemeyer, R. G., Boles, J. S., \& McMurrian, R. (1996). Development and validation of work-family conflict and family-work conflict scales. Journal of Applied Psychology, 81(4), 400 - 410.

Nomaguchi, K. \& Jonson, W. (2013). Employment, Work-Family Conflict, and Parenting Stress Among Economically Disadvantaged Fathers. Fragile Families Working Paper: 13-04-FF .1-40.

Perry-Jenkins, M., Repetti, R.L. \& Crouter, A. C. (2000). Work and Family in the 1990s. Journal of Marriage and the Family, 62(4), 98 1-998.

Pomerantz, E. M., Grolnick, W. S., \& Price, C. E. (2005). The role of parents in how children approach achievement. In A. J. Elliot \& C. S. Dweck (Eds.), Handbook of Competence and Motivation. New York: Guilford Press.

Radziszewska, B., Richardson, J. L., Dent, C. W., \& Flay, B. R. (1996). Parenting style and adolescent depressive symptoms, smoking, and academic achievement: Ethnic, gender, and SES differences. Journal of Behavioural Medicine, 19(3), 289-305.

Reid, M.J., Webster-Stratton, C. \& Baydar, N. (2004). Halting the development of conduct problems in head start children: the effects of parent training. Journal of Clinical Child \& Adolescent Psychology. 33, 279-291.

Sabattini, L. \& Campbell, L. (2004). The relationship between mothers' and fathers' parenting styles and their division of labour in the home: Young adults retrospective reports. Sex Role, 5(3), 217-225.

Sandler, I.N., Schoenfelder, E.N., Wolchik, S,A. \& MacKinnon, D.P. (2011). Long-term impact of prevention programs to promote effective parenting: Lasting effects but uncertain processes. Annual Review of Psychology. 62, 299-329.

Shreffler, K.M., Meadows, M.P. and Davis, K.D. (2011). Firefighting And Fathering: Work-Family Conflict, Parenting Stress, And Satisfaction With Parenting And Child Behaviour. Fathering, 9(2), 169-188.

Simons, R.L., Johnson, C., \& Conger, R.D. (1994). Harsh Corporal Punishment versus Quality Parental Involvement as an Explanation of 
Adolescent Maladjustment. Journal of Marriage and the Family,56(3), 591607.

Snyder, K. A. (2007). A Vocabulary of Motives: Understanding How Parents Define Quality Time. Journal of Marriage and the Family, 69,320-340.

Strage, A. \& Brandt, T.S. (1999). Authoritative parenting and college students' academic adjustment and success. Journal of Educational Psychology, 91(1), 146-156.

Tsai, H. (2008). Work-family conflict, positive spillover, and emotions among asian american working mothers. Unpublished $\mathrm{PhD}$ thesis, University of Michigan.

U.S. Bureau of Labor Statistics. (2002). Table 4. Families with own children: Employment status of parents by age of youngest child and family type, 20001 annual averages. Retrieved January 18, 2015, from http://www.bls.gov/news.release/famee.t04.htm.

Ugoani, J. N. N. (2013). Emotional Intelligence and Balancing Work Family-Conflict among Dual-Career-Parents in Nigeria. Management and Administrative Sciences Review, 2(5), 5 75-582

Van Hooff, M. L., Geurts, S. A., Kompier, M. A. \& Tans, T. W. (2006). Work-Home Interference: How Does it Manifest Itself from Day to Day? Work \& Stress, 20, 145-162.

Wigfield, A., Eccles, J. S., Schiefele, U., Roeser, R., \& DavisKean, P. (2006). Development of achievement motivation. In W. Damon and N. Eisenberg (Eds.), Handbook of Child Psychology (Vol. 3, 6th ed. pp. 9331002). New York: Wiley.

Winsler, A., Madigan, A.L. \& Aquilino, S.A. (2005). Correspondence between maternal and paternal parenting styles in early childhood. Early Childhood Research Quarterly 20(2005) 1-12

Zick, C. D., Keith, B.W. \& Osterbacka, E. (2001). Mothers' Employment, Parental Involvement, and the Implications for Intermediate Child Outcomes. Social Science Research, 30, 25-49. 